\title{
CORRESPONDENCE
}

\section{Acute Infectious Diarrhea in Children}

by Prof. Dr. med. Sibylle Koletzko, Stephanie Osterrieder in volume 33/2009

\section{Acute Purulent Appendicitis}

The authors do not include acute purulent appendicitis in their list of differential diagnoses. Clinical experience as well as the issue of medical liability, however, make an addendum necessary.

Purulent, usually already perforated, appendicitis is the most common and dangerous differential diagnosis for acute infectious enteritis, in children as well as in adults. Unpublished statistics from the North German arbitration board that relate to acute appendicitis show that some 345 cases were handled between 2000 and 2008; 277 of these were in adults and 68 in children. A complaint because of a delay in diagnosis and therapy was made in the cases of 153 adults (55\%) and 42 children (62\%). The misdiagnosis enteritis was the cause of the diagnostic delay in 56 adults (37\%) and 25 children (60\%). In 37 adults (66 \%) and 15 children (60\%), diagnostic errors were confirmed. In all cases the diagnostic delay resulted in severe disease courses; in the case of one adult the outcome was fatal. According to our own estimates the ratio of appendicitis associated diarrhea to infectious enteritis is about 1:100. In spite of this, the differential diagnosis should always be considered. Diarrhea as a symptom does not exclude appendicitis; rather, it is a typical symptom in locally advanced appendicitis, especially in patients with interenteric abscesses. I would recommend subtle palpation of the abdomen, paying attention to regionally different pain reactions and muscular guarding, and taking the patient's rectal temperature. Rectal examination, especially in young children, is not obligatory but often helpful, because pain symptoms in the pouch of Douglas or the right lower quadrant can be triggered in this way. If the diagnosis is likely to be non-enteritis related diarrhea, control examinations should be performed after 6-12 hours, followed by leukocyte and C-reactive protein tests and ultrasonography. Purulent appendicitis may occasionally occur as a comorbidity in patients with infectious enteritis.

DOl: 10.3238/arztebl.2010.0072a

\section{REFERENCES}

1. Vinz H, Neu J: Arzthaftpflichtverfahren im Zusammenhang mit der Diagnose und der Therapie der akuten Appendizitis Z Ärztliche Fortbildung Qualitätsgesundheitswesen ZaeFQ 2007; 101: 553-63.

2. Monse T, Tiedtge A: Aktuelle Aspekte der Diagnostik und Therapie der Appendizitis im Kindesalter. Zentralblatt Chirurgie 1998; 123 (Supplement 4): 80-81

3. Koletzko S, Osterrieder S: Acute infectious diarrhea in children. Dtsch Arztebl Int 2009; 106(33): 539-48.
Prof. Dr. med. Heinrich Vinz

Ärztliches Mitglied der Schlichtungsstelle für Arzthaftpflichtfragen

der norddeutschen Schlichtungsstelle

Hans-Böckler-Allee 3, 30173 Hannover, Germany

Behne@schlichtungsstelle.de

\section{Conflict of interest statement}

The author declares that no conflict of interest exists according to the guidelines of the International Committee of Medical Journal Editors.

\section{In Reply:}

We thank Professor Vinz for his helpful addendum that acute appendicitis should be considered as a differential diagnosis for infectious gastroenteritis. However, we do not share his view that appendicitis is the most common differential diagnosis for acute gastroenteritis and that the ratio is one case of appendicitis in every 100 cases of acute diarrhea. As we explained in our article, the acute gastroenteritis peaks in older infants and young toddlers, who experience an average of 2 episodes of diarrhea per year. Acute appendicitis, however, affects mainly school children; the ratio in this age group is 4 cases per 1000 children per year. By contrast, acute appendicitis is much rarer in infants and toddlers. In a retrospective analysis of the pediatric hospital in Toronto, which analyzed data from 28 years, only $2.3 \%$ of all children were younger than 3 years (1). However, an atypical presentation with delayed diagnosis and a high risk of perforation is common in these young children. $41 \%$ of toddlers with appendicitis had diarrhea, whereas this symptom was observed in less than $20 \%$ of school children. A systematic review has shown that in children who presented to emergency outpatient departments because of abdominal pain, fever and rebound tenderness were the best discriminators (positive likelihood ratio 3.4 and 3.0), whereas rectal examination, vomiting, diarrhea, and the leukocyte count were not that helpful (2). Acute appendicitis remains a clinical diagnosis. We agree with Vinz that if in doubt, a child should be admitted as an inpatient and should be thoroughly clinically evaluated.

DOl: 10.3238/arztebl.2010.0072b

\section{REFERENCES}

1. Alloo J, Gerstle T, Shilyansky J, Ein SH: Appendicitis in children less than 3 years of age: a 28-year review. Pediatr Surg Int 2004; 19: 777-9.

2. Bundy DG, Byerley JS, Liles EA, Perrin EM, Katznelson J, Rice HE: Does this child have appendicitis? JAMA 2007; 298: 438-51.

3. Koletzko S, Osterrieder S: Acute infectious diarrhea in children. Dtsch Arztebl Int 2009; 106(33): 539-48.

Prof. Dr. med. Sibylle Koletzko, Stephanie 0sterriede

Abt. für Päd. Gastroenterologie und Hepatologie, Dr. von Haunersches Kinderspital, Ludwig Maximilians Universität München,

Lindwurmstr. 4, 80337 München, Germany

Sibylle.Koletzko@med.uni-muenchen.de

\section{Conflict of interest statement}

Professor Koletzko has received study support from Fresenius and honoraria for speaking and advisory acitivities from Abbott, Danone, Fresenius, Hipp, and Sanofi-Pasteur. Ms Osterrieder has received support for conference participation from Danone. 